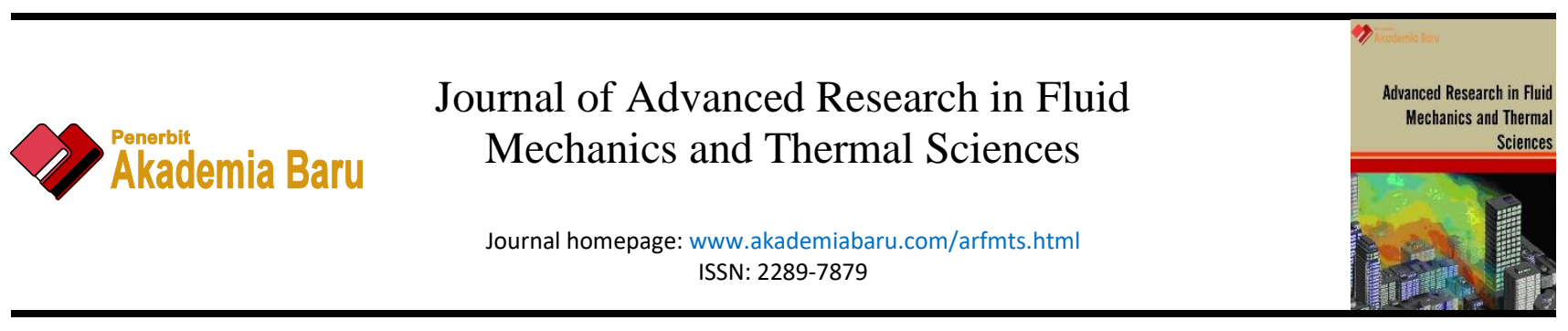

\title{
Electrical Characteristics of Photovoltaic Thermal Collector with Water-Titania Nanofluid Flow
}

\footnotetext{
1 Solar Energy Research Institute, Universiti Kebangsaan Malaysia, 43600 Bangi Selangor, Malaysia
}

\begin{tabular}{|c|c|}
\hline ARTICLE INFO & ABSTRACT \\
\hline $\begin{array}{l}\text { Article history: } \\
\text { Received } 15 \text { March } 2020 \\
\text { Received in revised form } 23 \text { May } 2020 \\
\text { Accepted } 30 \text { May } 2020 \\
\text { Available online } 31 \text { July } 2020\end{array}$ & $\begin{array}{l}\text { Photovoltaic thermal (PVT) studies show promising results from utilising waste heat } \\
\text { under PV panels during intense solar radiation. Heat removal is essentially the base of } \\
\text { a PVT collector. The heat absorption from the back of the PV panel is used for various } \\
\text { purposes. Collected solar energy is mostly converted into heat and needs to be } \\
\text { extracted to maintain PV efficiency. The PVT collector works similarly as a flat plate } \\
\text { solar collector, except that the short wavelengths are converted into electricity and the } \\
\text { remaining wavelengths into useful heat. The heat collected is also at a lower } \\
\text { magnitude than those collected by solar thermal collectors. This research presents an } \\
\text { experimental investigation that improves the efficiency of a PVT water collector with } \\
\text { and without titania }\left(\mathrm{TiO}_{2}\right) \text { nanofluid using a spiral absorber as a coolant. Results show } \\
\text { that the highest maximum power increase is obtained when the } 1.0 \text { wt\% } \mathrm{TiO}_{2} \text { nanofluid } \\
\text { is used as a coolant. In addition, the generated power increases with the addition of } \\
\text { solar radiation, and efficiency is slightly higher than that of the PVT water collector } \\
\text { without } \mathrm{TiO}_{2} \text {. The electrical characteristics of the PVT water collector are represented } \\
\text { by plotted current-voltage and power-voltage curves. }\end{array}$ \\
\hline
\end{tabular}

Keywords:

PVT; power; fill factor; efficiency; I-V curve; P-V curve

Copyright $\odot 2020$ PENERBIT AKADEMIA BARU - All rights reserved

\section{Introduction}

Growth in the field of renewable energy and the increasing energy efficiency have brought global stability. However, considerable carbon footprint is derived from the global use of energy and a decrease in the primary source of fossil fuels. Global awareness on the exploration of renewable energy has signalled that renewable energy would be an option in the future. Renewable energy to adapt to climate, continuous energy supply, new employment opportunities, nature and energy delivery to the interior. In 2013, renewable energy covered $19.1 \%$ of the world's total end energy use. Moreover, global renewable power capacity generated from electricity, wind and hydropower in 2014 was higher than in 2013 by $28 \%, 16 \%$ and 3.6\%, respectively. The global demand for renewable energy sources is increasing by $1.6 \%$ annually, especially for developing countries. The

\footnotetext{
* Corresponding author.

E-mail address: a.fudholi@ukm.edu.my
}

https://doi.org/10.37934/arfmts.73.2.2028 
government of Malaysia has provided targets for renewable energy of $2080 \mathrm{MW}$ by 2020 and 4000 MW by 2030. At present, advancements in the field of renewable energy influence various fields, such as transport, cooling, heating and power generation in rural areas. However, yearly savings from the use of renewable energy are far from the target rate. This problem may be due to the ongoing fossil fuel subsidies, the low efficiency of renewable energy technologies and the prohibitive costs [1-8].

Solar energy is converted into electric energy using photovoltaic (PV) technology. PV cells are limited in efficiency conversion when the temperature is raised and are responsive only to a portion of the solar spectrum. The solar cell conversion efficiency ranges from $6 \%$ to $18 \%$, which is a value measured at the nominal operating temperature, and the rest of solar radiation received are reflected and absorbed as heat energy. The low efficiency and high cost of PV cells brings about the idea of a hybrid PVT. The hybrid PVT is the integration of a solar thermal collector and a PV module. PVT enhances the electrical energy produced, removes waste heat from the PV module and minimises the usable space. Moreover, solar energy is converted into thermal energy as it is stored in air or water. PVT collectors can be classified into three categories: PVT air collectors, water PVT collectors and air/water PVT collectors. A PVT comprises a glass cover, a solar cell, encapsulated materials and a collector attached to the back. In terms of physical structure, the module could be classified as a flat plate of concentrated and building integrated types. The absorber receives the heat and simultaneously cools down the PV module. The collected heat is in the form of water or air. Heat energy can also be used for air heating during winter and production of hot water for bathing, washing, cooking and drying [9-18].

Recently, various studies have been conducted on PVT collectors with water and air as heat carriers. Experimental and theoretical studies on PVT collectors are also available in the literature [19-21]. Most studies have focused on the size, arrangement and type of fluid used for cooling in PVT, whereas studies using nanofluids as coolants are still at an early stage. In heat transfer applications, nanofluid has gained attention as new and efficient heat transfer fluid due to its superior thermophysical properties compared to conventional working fluid such as water, oil and ethylene glycol [22]. The emergence of advanced technology has produced nanoparticles, later dispersed in the fluid called as nanofluid enhanced heat transfer process substantially. The remarkable increase in thermal conductivity even when a low concentration of nanoparticles is added in fluid has been observed by many researchers [23]. One of the solutions is introducing foreign element of higher heat carrier capacity and thermal conductivity, known as nanoparticles which could improve the overall performance of heat transfer fluid [24]. Nanoparticles are materials produced via nanotechnology method. Nanoparticle physical properties, with size of less than $100 \mathrm{~nm}$, include various types of materials with particular substances [25,26]. Xu and Kleinstreuer [27] showed that $\mathrm{PV} / \mathrm{T}$ using nanofluids is more suitable for silicon solar cells compared with multijunction solar cells, and the overall energy conversion efficiency of the CPV/T system is higher than that of the conventional system. Yousefi et al., [28] investigated the efficiency of a flat plate solar water heater collector by varying the mass flow rate and volume concentration of alumina nanofluid. Results indicated that by increasing the mass flow rate from $1 \mathrm{~L} / \mathrm{min}$ to $3 \mathrm{~L} / \mathrm{min}$, the efficiency of the solar collector increased at a constant volume concentration. Sardarabadi et al., [29] conducted an experiment on the effect of silica/water nanofluid on PV/T and found that the total exergy for $1 \mathrm{wt} \%$ and 3 wt\% increased by $22.61 \%$ and $23.31 \%$, respectively, compared with a PV system with no collector. The main objective of the present study is to investigate the efficiencies of PVT water collectors with and without $\mathrm{TiO}_{2}$ nanofluid. 


\section{Materials and Methods}

The setup of the PVT system during the indoor experiment under a solar simulator is shown in Figure 1. A standard polycrystalline $80 \mathrm{~W}$ photovoltaic module represented as a flat plate unglazed sheet is attached on top. The collector, which consists of a single unilateral channel for fluid flow, is inserted underneath the PV module. The surface of the PV/T collector measures $0.5 \mathrm{~m}$ wide and 1.2 $\mathrm{m}$ long. A K-type thermocouple is used with a data logger for collecting the inlet and outlet fluid and the PV panel surface temperature. The change in temperature during the experiment can be tracked and recorded in a short step time $(1 \mathrm{~min})$. The total incident radiation on the system is measured by a pyranometer. A flow meter (1-4 G/M) is mounted at the opening of the fluid inlet to control the mass flow rate.

Spiral collecting spider tanks were selected in this study, according to Ibrahim et al., [30,31], Fudholi et al., [32] and Aisyah et al., [33]. The improvement of the looser form of this study was in the diameter of the absorber being raised to increase the touch surface area between the PV module and the absorber. The material used to make this absorber was a rust-proof patient. The conductivity of the terminus was $16.3 \mathrm{~W} / \mathrm{mK}$ to $20.0 \mathrm{~W} / \mathrm{mK}$. This material was selected because it is cheaper than copper and has high calorific resistance. Figure 2 shows the stainless spiral absorber. The width of the absorber is $1.9 \mathrm{~cm} \times 1.9 \mathrm{~cm}$ with a thickness of $1 \mathrm{~mm}$.

The experiment was conducted in an indoor testing facility using a solar simulator. The simulator consisted of 40 halogen lamps, and the intensity of solar radiation was controlled by a variable voltage controller. The PVT system was exposed to solar radiation of $900 \mathrm{~W} / \mathrm{m}^{2}$ for 40 min before data collection to ensure an equilibrium state of radiation. The change in voltage was recorded using an electric load under different mass flow rates and volume concentrations of nanofluid. The mass flow rate of water was $0.0255 \mathrm{~kg} / \mathrm{s}$. The temperature of the system was collected from the thermocouple stored in the data acquisition system ADAM every minute and subsequently used for calculating the electrical and thermal efficiencies of the collector. The water was circulated around the system using a pump and heat exchanger used for cooling the fluid in the closed-loop system. The cooling fluids used in this experiment were water and $\mathrm{TiO}_{2} /$ water with $0.5 \mathrm{wt} \%$ and $1.0 \mathrm{wt} \%$ concentrations, respectively. Nanofluids were prepared with a sonicator, and a stabilizer was added. The sonication process for dispersing nanoparticles in distilled water lasted approximately $1 \mathrm{~h}$. The zeta potential was used to examine the stability of the prepared nanofluid. The properties of fluid used are stated in Table 1.

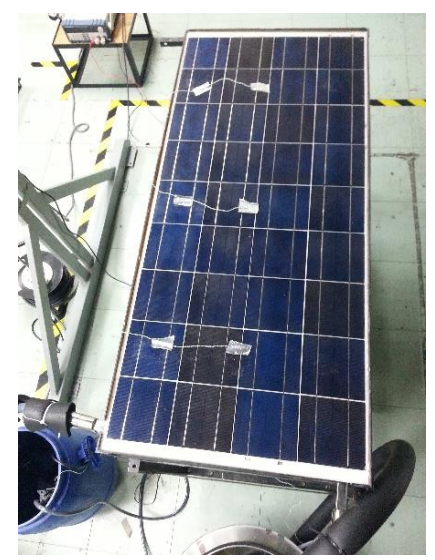

Fig. 1. PVT water collector under a solar simulator

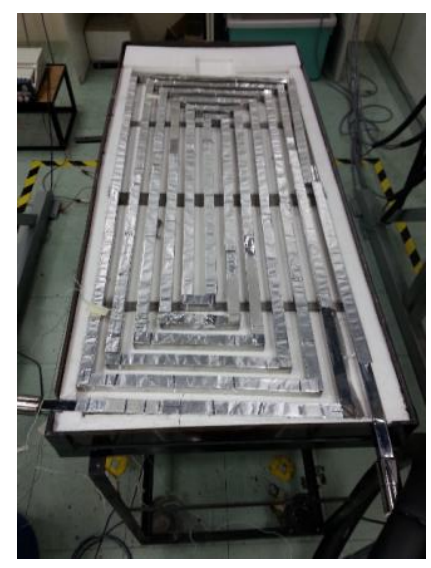

Fig. 2. Spiral absorber attached to the back of the PV 


\section{Table 1}

Fluid properties

\begin{tabular}{lllll}
\hline Fluid & Particle Size $(\mathrm{nm})$ & Heat Capacity $(\mathrm{J} / \mathrm{kgK}$ & Density $(\mathrm{kg} / \mathrm{m} 3)$ & Thermal Conductivity $(\mathrm{W} / \mathrm{mK})$ \\
\hline $\mathrm{TiO}_{2} /$ water & 25 & 690 & 3900 & 8.9
\end{tabular}

Electrical data collection for current, voltage, short circuit current (Isc) and open circuit voltage (Voc) used an electronic load of an 8500 model from BK Precision. Data obtained were used to plot the I-V curve graph, from which the maximum power $(\mathrm{Pm})$ can be determined.

The fill factor (FF) of a PVT water collector is a measurement of the real I-V characteristic curve. It is defined as the maximum power ratio $\left(\mathrm{P}_{\mathrm{m}}\right)$ produced by the cell against the open circuit voltage product $\left(\mathrm{V}_{\mathrm{oc}}\right)$ and the closed circuit current $\left(\mathrm{I}_{\mathrm{sc}}\right)$. The FF can be written as

$$
F F=\frac{P_{m}}{V_{o c} \times I_{s c}}
$$

The electrical efficiency of the PVT water collector is measured by the maximum power ratio $\left(\mathrm{P}_{\mathrm{m}}\right)$ to the intended radiation.

$\eta_{p v}=\frac{P_{m}}{S A_{c}}$

where $A_{c}$ is the surface area of the collector, $S$ is the intensity of radiation, and $P_{m}$ is derived from the equation.

$P_{m}=V_{m} \times I_{m}$

The features of a PV module could be removed from the PV module output, which could be explained by the resulting I-V curve. The curve changed as a function of the PV temperature $\left(T_{p v}\right)$ and of the solar radiation $(\mathrm{S})$ received by the module.

\section{Results and Discussion}

PVT water collectors with and without $\mathrm{TiO}_{2}$ nanofluid were tested in a laboratory. The effect of mass flow rate change on the PVT water collector without $\mathrm{TiO}_{2}$ nanofluid is shown in Table 2 . At a mass flow rate of $0.012 \mathrm{~kg} / \mathrm{s}$ and with the solar radiation changed from $500 \mathrm{~W} / \mathrm{m}^{2}$ to $900 \mathrm{~W} / \mathrm{m}^{2}, \mathrm{I}_{\mathrm{sc}}$ increased from $0.841 \mathrm{~A}$ to $2.018 \mathrm{~A}$, and $\mathrm{V}_{\text {oc }}$ decreased from $17.52 \mathrm{~V}$ to $17.00 \mathrm{~V}$. The resulting power also increased from $9.853 \mathrm{~W}$ to $22.823 \mathrm{~W}$ under the same solar radiation. The increase in $\mathrm{I}_{\mathrm{sc}}$ and the decrease in $\mathrm{V}_{\text {oc }}$ were recorded when the water flow rate was changed to $0.0255 \mathrm{~kg} / \mathrm{s}$, whereas the maximum power was recorded at $5.04 \%, 4.36 \%$ and $3.32 \%$ at 500,700 and $900 \mathrm{~W} / \mathrm{m}^{2}$, respectively, under the same mass flow rate ranging from $0.012 \mathrm{~kg} / \mathrm{s}$ to $0.0255 \mathrm{~kg} / \mathrm{s}$.

Table 2

Effect of radiation intensity and mass flow rate on the $\mathrm{V}_{\mathrm{oc}}$ and $\mathrm{I}_{\mathrm{sc}}$ of the PVT water collector

\begin{tabular}{|c|c|c|c|c|c|c|}
\hline \multirow{2}{*}{$\begin{array}{l}\mathrm{S} \\
\left(\mathrm{W} / \mathrm{m}^{2}\right)\end{array}$} & \multicolumn{3}{|c|}{$\dot{\mathrm{m}}=0.012 \mathrm{~kg} / \mathrm{s}$} & \multicolumn{3}{|c|}{$\dot{\mathrm{m}}=0.0255 \mathrm{~kg} / \mathrm{s}$} \\
\hline & $\begin{array}{l}\mathrm{I}_{\mathrm{sc}} \\
(\mathrm{A})\end{array}$ & $V_{\text {oc }}(V)$ & $\begin{array}{l}P_{m} \\
(W)\end{array}$ & $\begin{array}{l}\mathrm{I}_{\mathrm{sc}} \\
(\mathrm{A})\end{array}$ & $V_{o c}(V)$ & $\begin{array}{l}P_{m} \\
(W)\end{array}$ \\
\hline 500 & 0.841 & 17.52 & 9.853 & 0.878 & 17.33 & 10.336 \\
\hline 700 & 1.360 & 17.35 & 16.029 & 1.424 & 17.05 & 16.728 \\
\hline 900 & 2.018 & 17.00 & 22.823 & 2.080 & 16.84 & 23.580 \\
\hline
\end{tabular}


After testing the PVT water collector without $\mathrm{TiO}_{2}$ nanofluid, the optimum fluid flow rate was determined at $0.0255 \mathrm{~kg} / \mathrm{s}$. The PVT collector was studied with various $\mathrm{TiO}_{2}$ nanofluids at different concentrations ( $0.5 \mathrm{wt} \%$ and $1.0 \mathrm{wt} \%$ ). Figures 3 to 5 show the $\mathrm{I}-\mathrm{V}$ and $\mathrm{P}-\mathrm{V}$ curves at the mass flow rate of $0.0255 \mathrm{~kg} / \mathrm{s}$ and solar radiation of $500 \mathrm{~W} / \mathrm{m}^{2}$ to $900 \mathrm{~W} / \mathrm{m}^{2}$ and are summarized in Table 3 . For the PVT water collector without $\mathrm{TiO}_{2}$ nanofluid, $\mathrm{I}_{\mathrm{sc}}$ increased from $0.878 \mathrm{~A}$ to $2.080 \mathrm{~A}$ when the solar radiation changed from $500 \mathrm{~W} / \mathrm{m}^{2}$ to $900 \mathrm{~W} / \mathrm{m}^{2}$, whereas for the PVT water collector with $0.5 \mathrm{wt} \%$ and $1.0 \mathrm{wt} \%$, $\mathrm{I}_{\mathrm{sc}}$ increased from $0.951 \mathrm{~A}$ to $2.146 \mathrm{~A}$ and $0.967 \mathrm{~A}$ to $2.211 \mathrm{~A}$, respectively. Meanwhile, the $\mathrm{V}_{\text {oc }}$ for the PVT water collector without $\mathrm{TiO}_{2}$ nanofluid decreased from $17.43 \mathrm{~V}$ to $16.84 \mathrm{~V}$, whereas for the PVT water collector with $0.5 \mathrm{wt} \% \mathrm{TiO}_{2}$ nanofluid, $\mathrm{V}_{\text {oc }}$ decreased from $17.31 \mathrm{~V}$ to 16.92 $\mathrm{V}$. $\mathrm{V}_{\mathrm{oc}}$ for the PVT water collector with $1.0 \mathrm{wt} \% \mathrm{TiO}_{2}$ nanofluid changed from $17.26 \mathrm{~V}$ to $16.73 \mathrm{~V}$. Maximum power increase was recorded when solar radiation changed from $500 \mathrm{~W} / \mathrm{m}^{2}$ to $900 \mathrm{~W} / \mathrm{m}^{2}$, as shown in Table 3. The maximum power generated from the PVT water collector without $\mathrm{TiO}_{2}$ was $10.336 \mathrm{~W}$ to $23.58 \mathrm{~W}$, whereas for the PVT water collector with $0.5 \mathrm{wt} \%$ and $1.0 \mathrm{wt} \% \mathrm{TiO}_{2}$, the maximum power increase was from $10.894 \mathrm{~W}$ to $24.012 \mathrm{~W}$ and $11.316 \mathrm{~W}$ to $24.453 \mathrm{~W}$, respectively.

Table 3

Effect of radiation intensity on the $\mathrm{V}_{\mathrm{oc}}$ and $\mathrm{I}_{\mathrm{sc}}$ of the PVT water collector with and without $\mathrm{TiO}_{2}$

\begin{tabular}{lllllll}
\hline $\begin{array}{l}\mathrm{S} \\
\left(\mathrm{W} / \mathrm{m}^{2}\right)\end{array}$ & $\mathrm{TiO}_{2}$ & $\begin{array}{l}\mathrm{I}_{\mathrm{sc}} \\
(\mathrm{A})\end{array}$ & $\begin{array}{l}\mathrm{V}_{\mathrm{oc}} \\
(\mathrm{V})\end{array}$ & $\begin{array}{l}\mathrm{P}_{\mathrm{m}} \\
(\mathrm{W})\end{array}$ & $\mathrm{FF}$ & $\begin{array}{l}\eta_{e l} \\
(\%)\end{array}$ \\
\hline \multirow{3}{*}{500} & Without & 0.878 & 17.43 & 10.336 & 0.679 & 3.32 \\
& $0.5 \mathrm{wt} \%$ & 0.951 & 17.31 & 10.894 & 0.670 & 3.50 \\
& 1.0 wt\% & 0.967 & 17.26 & 11.316 & 0.686 & 3.64 \\
700 & Without & 1.424 & 17.25 & 16.728 & 0.689 & 3.68 \\
& 0.5 wt\% & 1.476 & 17.10 & 17.200 & 0.685 & 3.77 \\
& 1.0 wt\% & 1.516 & 16.97 & 18.020 & 0.705 & 3.96 \\
900 & Without & 2.080 & 16.84 & 23.580 & 0.673 & 4.01 \\
& 0.5 wt\% & 2.146 & 16.92 & 24.012 & 0.673 & 4.08 \\
& 1.0 wt\% & 2.211 & 16.73 & 24.453 & 0.669 & 4.16 \\
\hline
\end{tabular}

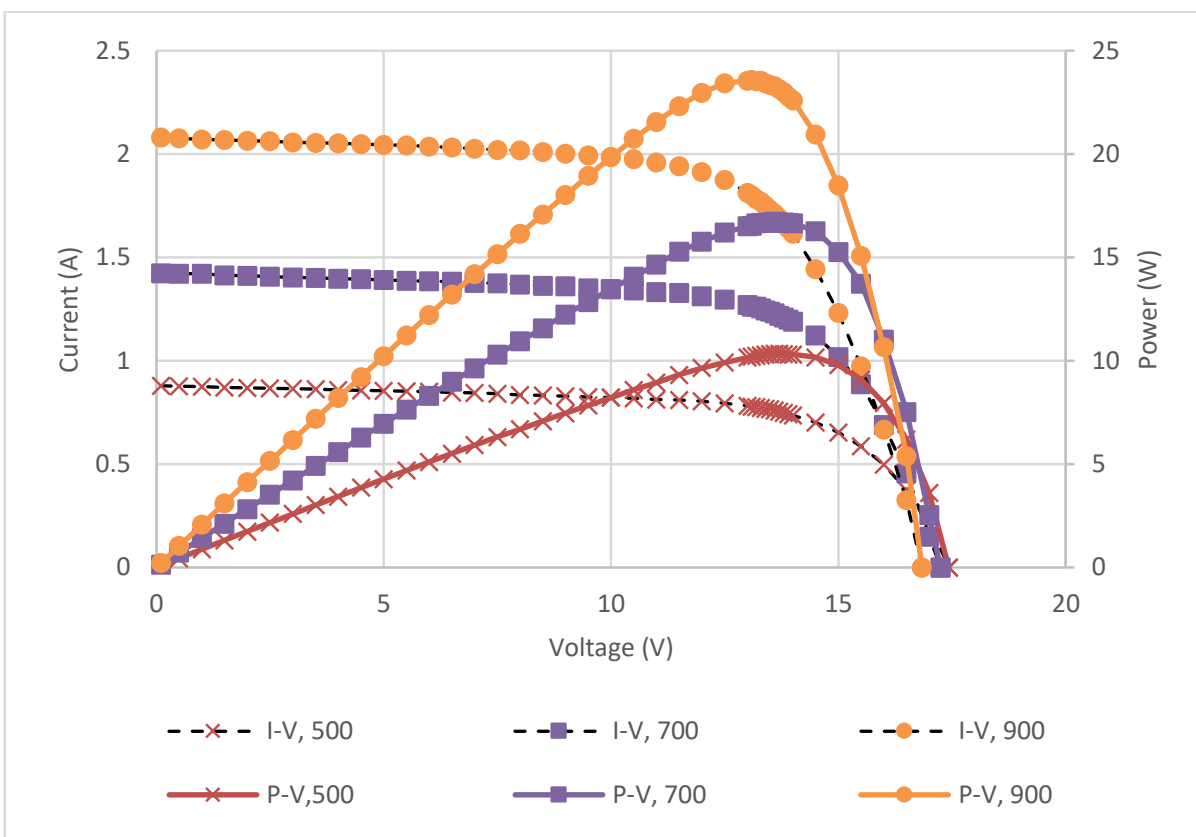

Fig. 3. Current $(\mathrm{I})$ and power $(\mathrm{P})$ over voltage $(\mathrm{V})$ for the $\mathrm{PVT}$ water collector without $\mathrm{TiO}_{2}$ at a solar radiation of $500 \mathrm{~W} / \mathrm{m}^{2}$ to $900 \mathrm{~W} / \mathrm{m}^{2}$ 


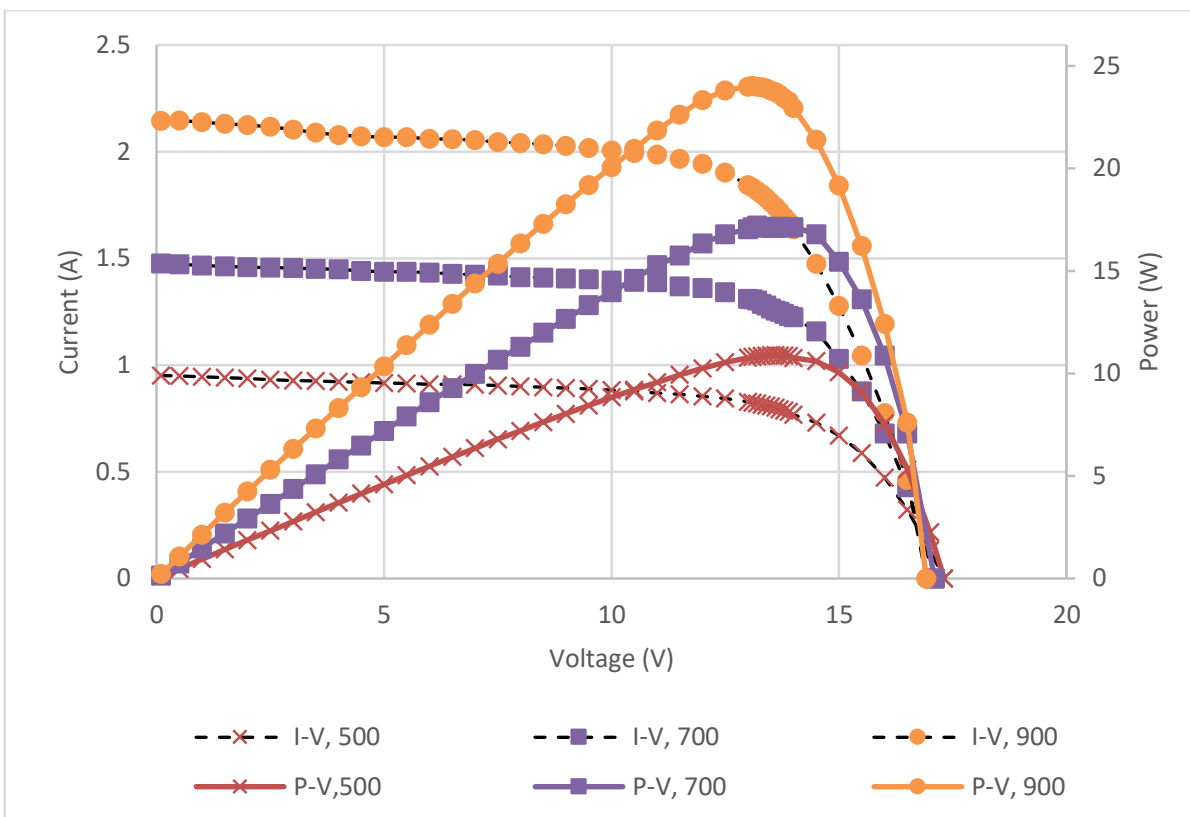

Fig. 4. Current $(\mathrm{I})$ and power $(\mathrm{P})$ over voltage $(\mathrm{V})$ for the PVT water collector with $0.5 \mathrm{wt} \% \mathrm{TiO}_{2}$ at a solar radiation of $500 \mathrm{~W} / \mathrm{m}^{2}$ to $900 \mathrm{~W} / \mathrm{m}^{2}$

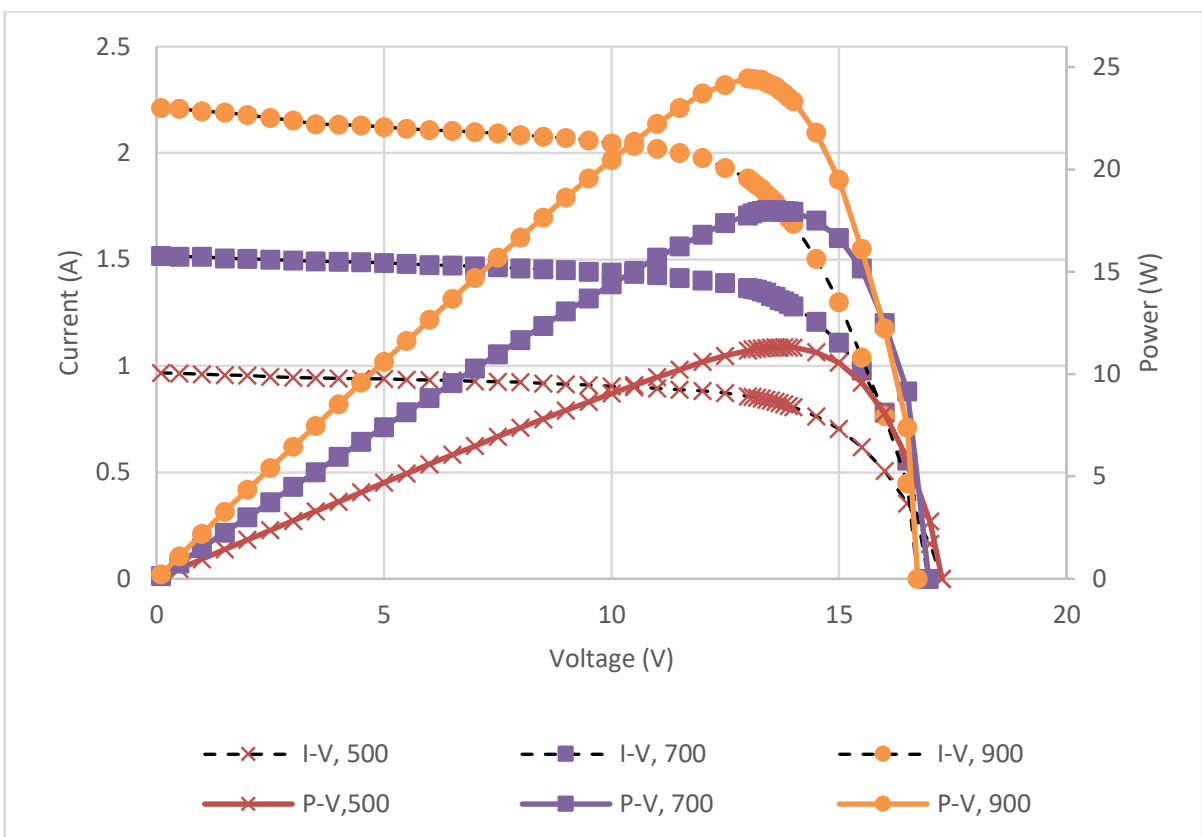

Fig. 5. Current $(\mathrm{I})$ and power $(\mathrm{P})$ over voltage $(\mathrm{V})$ for the PVT water collector with $1.0 \mathrm{wt} \% \mathrm{TiO}_{2}$ at a solar radiation of $500 \mathrm{~W} / \mathrm{m}^{2}$ to $900 \mathrm{~W} / \mathrm{m}^{2}$

\section{Conclusions}

Results lead to the following conclusions.

i. The generated power increases with the addition of solar radiation, and efficiency is slightly higher than that of the PVT water collector without $\mathrm{TiO}_{2}$ nanofluid.

ii. The highest maximum power increase is obtained when $1.0 \mathrm{wt} \% \mathrm{TiO}_{2}$ nanofluid is used as a coolant in the PVT collector. 
iii. The increase in efficiency of $\mathrm{TiO}_{2}$ fluid at $0.5 \%$ and $1.0 \%$ concentrations at the same conditions was recorded at $10.57 \%$ and $12.74 \%$.

\section{Acknowledgement}

The authors would like to thank Universiti Kebangsaan Malaysia (UKM) for funding (FRGS/1/2014/ST02/UKM/03/1) and (GGP-2017-045), Prof. Dr. Zahari Ibrahim for the indoor testing in the Physics Laboratory (Solar Simulator Lab) and the Solar Energy Research Institute, UKM.

\section{References}

[1] Yahya, M., Ahmad Fudholi, and Kamaruzzaman Sopian. "Energy and exergy analyses of solar-assisted fluidized bed drying integrated with biomass furnace." Renewable Energy 105 (2017): 22-29.

https://doi.org/10.1016/i.renene.2016.12.049

[2] Yahya, Muhammad, Ahmad Fudholi, Hadyan Hafizh, and Kamaruzzaman Sopian. "Comparison of solar dryer and solar-assisted heat pump dryer for cassava." Solar Energy 136 (2016): 606-613.

https://doi.org/10.1016/i.solener.2016.07.049

[3] Fudholi, Ahmad, Muhammad Zohri, Goh Li Jin, Adnan Ibrahim, Chan Hoy Yen, Mohd Yusof Othman, Mohd Hafidz Ruslan, and Kamaruzzaman Sopian. "Energy and exergy analyses of photovoltaic thermal collector with $\nabla$ groove." Solar Energy 159 (2018): 742-750.

https://doi.org/10.1016/i.solener.2017.11.056

[4] Fudholi, Ahmad, and Kamaruzzaman Sopian. "R\&D of Photovoltaic Thermal (PVT) Systems: an overview." International Journal of Power Electronics and Drive Systems 9, no. 2 (2018): 803-810. https://doi.org/10.11591/ijpeds.v9.i2.pp803-810

[5] Fudholi, Ahmad, and Kamaruzzaman Sopian. "Review on exergy and energy analysis of solar air heater." International Journal of Power Electronics and Drive Systems 9, no. 1 (2018): 420-426.

https://doi.org/10.11591/ijpeds.v9.i1.pp420-426

[6] Fudholi, Ahmad, and Kamaruzzaman Sopian. "Review on solar collector for agricultural produce." International Journal of Power Electronics and Drive Systems 9, no. 1 (2018): 414-419.

https://doi.org/10.11591/ijpeds.v9.i1.pp414-419

[7] Fudholi, Ahmad, Lim Chin Haw, Kamaruzzaman Sopian, and Ahmed Mohamed Omer Abdulmula. "Primary study of tracking photovoltaic system for mobile station in Malaysia." International Journal of Power Electronics and Drive Systems 9, no. 1 (2018): 427-432.

https://doi.org/10.11591/ijpeds.v9.i1.pp427-432

[8] Fudholi, Ahmad, Kamaruzzaman Sopian, Mohamed Gabbasa, Ba Bakhtyar, M. Yahya, Mohd Hafidz Ruslan, and Sohif Mat. "Techno-economic of solar drying systems with water based solar collectors in Malaysia: a review." Renewable and Sustainable Energy Reviews 51 (2015): 809-820.

https://doi.org/10.1016/j.rser.2015.06.059

[9] Fudholi, Ahmad, Kamaruzzaman Sopian, B. Bakhtyar, Mohamed Gabbasa, Mohd Yusof Othman, and Mohd Hafidz Ruslan. "Review of solar drying systems with air based solar collectors in Malaysia." Renewable and Sustainable Energy Reviews 51 (2015): 1191-1204. https://doi.org/10.1016/i.rser.2015.07.026

[10] Fudholi, Ahmad, Muhammad Zohri, Nurul Shahirah Binti Rukman, Nurul Syakirah Nazri, Muslizainun Mustapha, Chan Hoy Yen, Masita Mohammad, and Kamaruzzaman Sopian. "Exergy and sustainability index of photovoltaic thermal (PVT) air collector: A theoretical and experimental study." Renewable and Sustainable Energy Reviews 100 (2019): 44-51.

https://doi.org/10.1016/i.rser.2018.10.019

[11] Fudholi, Ahmad, Kamaruzzaman Sopian, M. A. Alghoul, Mohd Hafidz Ruslan, and Mohd Yusof Othman. "Performances and improvement potential of solar drying system for palm oil fronds." Renewable Energy 78 (2015): 561-565. https://doi.org/10.1016/i.renene.2015.01.050

[12] Sopian, Kamaruzzaman, Ali HA Alwaeli, Husam Abdulrasool Hasan, and Ali Najah Al-Shamani. "Advances in high efficiency photovoltaic thermal solar collectors." Journal of Advanced Research in Fluid Mechanics and Thermal Sciences 47, no. 1 (2018): 1-7.

[13] Abdullah, Ahmed L., S. Misha, N. Tamaldin, M. A. M. Rosli, and F. A. Sachit. "Photovoltaic thermal/solar (PVT) collector (PVT) system based on fluid absorber design: A review." Journal of Advanced Research in Fluid Mechanics and Thermal Sciences 48, no. 2 (2018): 196-208. 
[14] Singh, Baljit Singh Sarban, Chan Hoy Yen, Saleem Hussain Zaidi, and Kamaruzzaman Sopian. "Part II: enhanced performance of concentrating photovoltaic-thermal air collector with fresnel lens and compound parabolic concentrator (CPC)." Journal of Advanced Research in Fluid Mechanics and Thermal Sciences 47, no. 1 (2018): 1624.

[15] Rahman, M. M. "Energy Co-Generation in Photovoltaic Thermal-Collector (PVT) System: A Significant Increase in Efficiency." Journal of Advanced Research in Fluid Mechanics and Thermal Sciences 21, no. 1 (2016): 13-20.

[16] Fudholi, Ahmad, Mohd Yusof Othman, Mohd Hafidz Ruslan, and Kamaruzzaman Sopian. "Drying of Malaysian Capsicum annuum L.(red chili) dried by open and solar drying." International Journal of Photoenergy 2013 (2013): 1-9. https://doi.org/10.1155/2013/167895

[17] Fudholi, Ahmad, B. Bakhtyar, Habibis Saleh, Mohd Hafidz Ruslan, Mohd Yusof Othman, and Kamaruzzaman Sopian. "Drying of salted silver jewfish in a hybrid solar drying system and under open sun: Modeling and performance analyses." International journal of green energy 13, no. 11 (2016): 1135-1144. https://doi.org/10.1080/15435075.2016.1175347

[18] Zohri, Muhammad, Nurato Nurato, and Ahmad Fudholi. "Photovoltaic thermal (PVT) system with and without fins collector: theoretical approach." International Journal of Power Electronics and Drive Systems 8, no. 4 (2017): 17561763.

https://doi.org/10.11591/ijpeds.v8.i4.pp1756-1763

[19] Zohri, Muhammad, Lalu Darmawan Bakti, and Ahmad Fudholi. "Exergy assessment of photovoltaic thermal with vgroove collector using theoretical study." Telkomnika 16, no. 2 (2018): 550-557. https://doi.org/10.12928/telkomnika.v16i2.8433

[20] Nazri, Nurul Syakirah, Ahmad Fudholi, Bardia Bakhtyar, Chan Hoy Yen, Adnan Ibrahim, Mohd Hafidz Ruslan, Sohif Mat, and Kamaruzzaman Sopian. "Energy economic analysis of photovoltaic-thermal-thermoelectric (PVT-TE) air collectors." Renewable and Sustainable Energy Reviews 92 (2018): 187-197.

https://doi.org/10.1016/i.rser.2018.04.061

[21] Nazri, Nurul Syakirah, Ahmad Fudholi, Mohd Hafidz Ruslan, and Kamaruzzaman Sopian. "Mathematical modeling of photovoltaic thermal-thermoelectric (PVT-TE) air collector." International Journal of Power Electronics and Drive Systems 9, no. 2 (2018): 795-802.

https://doi.org/10.11591/ijpeds.v9.i2.pp795-802

[22] Xian, Hong Wei, Nor Azwadi Che Sidik, Siti Rahmah Aid, Tan Lit Ken, and Yutaka Asako. "Review on preparation techniques, properties and performance of hybrid nanofluid in recent engineering applications." Journal of Advanced Research in Fluid Mechanics and Thermal Sciences 45, no. 1 (2018):1-13.

[23] Ghadimi, A., Rahman Saidur, and H. S. C. Metselaar. "A review of nanofluid stability properties and characterization in stationary conditions." International journal of heat and mass transfer 54, no. 17-18 (2011): 4051-4068. https://doi.org/10.1016/j.ijheatmasstransfer.2011.04.014

[24] Sidik, Nor Azwadi Che, Tung Hao Kean, Hoong Kee Chow, Aravinthan Rajaandra, Saidur Rahman, and Jesbains Kaur. "Performance enhancement of cold thermal energy storage system using nanofluid phase change materials: a review." International Communications in Heat and Mass Transfer 94 (2018): 85-95. https://doi.org/10.1016/j.icheatmasstransfer.2018.03.024

[25] Mohamad, Ahmad Tajuddin, Jesbains Kaur, Nor Azwadi Che Sidik, and Saidur Rahman. "Nanoparticles: A review on their synthesis, characterization and physicochemical properties for energy technology industry." Journal of Advanced Research in Fluid Mechanics and Thermal Sciences 46, no. 1 (2018): 1-10.

[26] Muhammad, Nura Mu'az, and Nor Azwadi Che Sidik. "Applications of nanofluids and various minichannel configurations for heat transfer improvement: A review of numerical study." Journal of Advanced Research in Fluid Mechanics and Thermal Sciences 46, no. 1 (2018): 49-61.

[27] Xu, Zelin, and Clement Kleinstreuer. "Concentration photovoltaic-thermal energy co-generation system using nanofluids for cooling and heating." Energy Conversion and Management 87 (2014): 504-512. https://doi.org/10.1016/i.enconman.2014.07.047

[28] Yousefi, Tooraj, Farzad Veysi, Ehsan Shojaeizadeh, and Sirus Zinadini. "An experimental investigation on the effect of Al2O3-H2O nanofluid on the efficiency of flat-plate solar collectors." Renewable Energy 39, no. 1 (2012): $293-$ 298.

https://doi.org/10.1016/i.renene.2011.08.056

[29] Sardarabadi, Mohammad, Mohammad Passandideh-Fard, and Saeed Zeinali Heris. "Experimental investigation of the effects of silica/water nanofluid on PV/T (photovoltaic thermal units)." Energy 66 (2014): 264-272. https://doi.org/10.1016/i.energy.2014.01.102 
[30] Ibrahim, Adnan, Ahmad Fudholi, Kamaruzzaman Sopian, Mohd Yusof Othman, and Mohd Hafidz Ruslan. "Efficiencies and improvement potential of building integrated photovoltaic thermal (BIPVT) system." Energy Conversion and Management 77 (2014): 527-534.

https://doi.org/10.1016/i.enconman.2013.10.033

[31] Ibrahim, A., \& Jin, G. L. (2009). Hybrid Photovoltaic Thermal (PV/T) Air and Water Based Solar Collectors Suitable for Building Integrated Applications Adnan Ibrahim, Goh Li Jin, Roonak Daghigh, Mohd Huzmin Mohamed Salleh, Mohd Yusof Othman, Mohd Hafidz Ruslan, Sohif Mat and Kamaruzzaman Sopian Solar Energy Research Institute, University Kebangsaan Malaysia, 43600, Bangi, Selangor, Malaysia. American journal of environmental sciences, 5(5), 618-624.

https://doi.org/10.3844/ajessp.2009.618.624

[32] Fudholi, Ahmad, Kamaruzzaman Sopian, Mohammad H. Yazdi, Mohd Hafidz Ruslan, Adnan Ibrahim, and Hussein A. Kazem. "Performance analysis of photovoltaic thermal (PVT) water collectors." Energy conversion and management 78 (2014): 641-651.

https://doi.org/10.1016/j.enconman.2013.11.017

[33] Aisyah, Cheku Nurul, Ahmad Fudholi, Mohd Yusof Othman, Adnan Ibrahim, Mohd Hafidz Ruslan, and Kamaruzzaman Sopian. "Kecekapan pengumpul PV/T menggunakan pengumpul terma reka bentuk pilin." Sains Malaysiana 47, no. 4 (2018): 853-859.

https://doi.org/10.17576/ism-2018-4704-25 